\title{
Effects of ions on the motility of fresh and demembranated paddlefish (Polyodon spathula) spermatozoa
}

\author{
O. Linhart ${ }^{1}$, J. Cosson ${ }^{2}$, S. D. Mims ${ }^{3}$, \\ W. L. Shelton ${ }^{4}$ and M. Rodina ${ }^{1}$ \\ ${ }^{1}$ Joint Laboratory of Genetics, Physiology and Reproduction of Fish, Institute of Animal \\ Physiology and Genetics, Academy of Sciences of the Czech Republic, University of South \\ Bohemia, Research Institute of Fish Culture and Hydrobiology, 38925 Vodnany, Czech \\ Republic; ${ }^{2}$ Centre National de la Recherche Scientifique, UMR 7009, Université Paris 6, \\ Station Marine, 06230 Villefranche sur Mer, France; ${ }^{3}$ Aquaculture Research Center, \\ Kentucky State University, Frankfort, KY 40601, USA; and ${ }^{4}$ Zoology Department \\ University of Oklahoma, Norman, OK 73019, USA
}

This study investigated the effects of different environmental conditions on the motility parameters of paddlefish (Polyodon spathula) spermatozoa. Paddlefish spermatozoa demonstrated the following characteristics: (i) all spermatozoa were motile $10 \mathrm{~s}$ after activation with a velocity of $130-160 \mu \mathrm{m} \mathrm{s}^{-1}$; (ii) after $2 \mathrm{~min}$, velocity decreased to 80-130 $\mu \mathrm{m} \mathrm{s}^{-1}$; and (iii) motility was maintained for up to

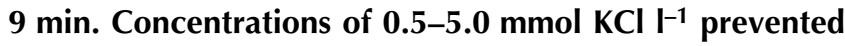
activation of spermatozoa. After transfer into a swimming medium (20 mmol Tris $\mathrm{I}^{-1}, \mathrm{pH} 8.2$ and $1 \mathrm{mg} \mathrm{BSA} \mathrm{ml}^{-1}$ ) con-

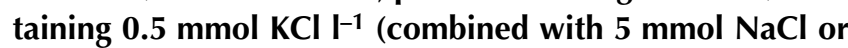
$\left.\mathrm{MgCl}_{2} \mathrm{I}^{-1}\right), 80-100 \%$ of cells were motile with a velocity of about $120-150 \mu \mathrm{m} \mathrm{s} \mathrm{s}^{-1} . \mathrm{MgCl}_{2}$ significantly improved the velocity of spermatozoa at 10, 40, 50 and $60 \mathrm{~s}$ after activation and the stable velocity of spermatozoa was about $140 \mu \mathrm{m} \mathrm{s}^{-1}$. Very low concentrations of $\mathrm{CaCl}_{2}(0.125 \mathrm{mmol}$

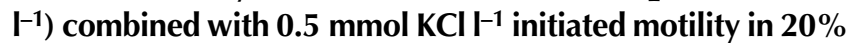
of spermatozoa, whereas all spermatozoa were activated after 2 min with 0.25 mmol $\mathrm{CaCl}_{2} \mathrm{I}^{-1}$ in similar medium for the full period of swimming with velocity of about $120 \mu \mathrm{m}$ $\mathrm{s}^{-1}$. This study demonstrated that potassium (5-15 $\left.\mathrm{mmol}^{-1}\right)$ inhibits demembranated spermatozoa. Thus, initiation of movement in paddlefish spermatozoa is under the reciprocal control of potassium and calcium ion concentrations.

\section{Introduction}

Two species from the family Polyodontidae are extant: the American paddlefish (Polyodon spathula) which is confined to North America, and the Chinese paddlefish (Psephurus gladius) which is native to mainland China. Both species were commercially important, but numbers have declined markedly over the past 100 years (Carlson and Bonislawsky, 1981; Gengerke, 1986; Liu and Zeng, 1988; Mims et al., 1993a). Artificial propagation and stocking have been successful only for the North American species. Wild stocks have been harvested for flesh and caviar production, and $P$. spathula is a popular sport fish in some areas in the USA (Gengerke, 1986; Liu and Zeng, 1988). P. spathula can reach a maximum of $83.5 \mathrm{~kg}$ and $216 \mathrm{~cm}$ in length (Adams, 1942; Folz and Mezers, 1985) and P. gladius grows much larger. $P$. spathula feeds on plankton, especially copepods, some insects, algae and plant fragments, whereas $P$. gladius is piscivorous (Mims et al., 1993a). Adult P. spathula filter zooplankton (microscopic food) through their gill rakers while swimming with their mouth open (Mims et al., 1993b;

Email: linhart@vurh.jcu.cz

Kroll et al., 1994). The spawning period of $P$. spathula is in early spring, when adults migrate upstream in the Mississippi River and its major tributaries. Spawning occurs from the middle of March to the end of May at $11-14^{\circ} \mathrm{C}$ in the Ohio River (Purkett, 1963; Ballard and Needham, 1964) or from April to June at $16^{\circ} \mathrm{C}$ in the Missouri River (Purkett, 1963; Ballard and Needham, 1964). Needham (1965) and Graham et al. (1986) developed artificial reproductive methods for paddlefish in the USA, and Mims and Shelton (1998) have modified this procedure.

Spermatozoa of sturgeons and paddlefish are essentially immotile in the seminal plasma (Linhart et al., 1995; Cosson and Linhart, 1996; Cosson et al., 2000). Spermatozoa are immediately activated when they are transferred into swimming medium, usually fresh water or low salt concentration solutions (Drabkina, 1961), in a similar way to spermatozoa of freshwater teleosts. Sperm motility is greatest immediately after activation. All sperm motility parameters (frequency, velocity and wave amplitude) decrease rapidly during the period after activation and the percentage of motile cells also gradually decreases (Cosson et al., 2000). During the earliest period of motility, spermatozoa of sturgeons and paddlefish move at velocities of $175-250 \mu \mathrm{ms}^{-1}$ 
(Cosson et al., 2000) and then the forward motility gradually reduces to between 50 and $100 \mu \mathrm{m} \mathrm{s}^{-1}$ at 3-6 min after activation, even when considering only the fraction of the population of cells with forward motility. Occasionally, some spermatozoa are motile for up to 9 min (Cosson et al., 2000). The concentration and ratio of ions in seminal fluid is important for maintaining energy. The motility of paddlefish spermatozoa is partly controlled by osmotic pressure (Linhart et al., 1995), as described for freshwater cyprinids (Redondo-Müller et al., 1991) and for marine fish (Morisawa and Suzuki, 1980). When the concentration or ratio of $\mathrm{Na}^{+}: \mathrm{K}^{+}$or the osmotic pressure change, sperm motility in sturgeon and paddlefish is initiated (Linhart et al., 1995; Cosson and Linhart, 1996; Toth et al., 1997; Cosson et al., 2000). A concentration of $\geqslant 0.5 \mathrm{mmol} \mathrm{K} \mathrm{I}^{-1}$ prevents motility of white sturgeon (Acipenser fulvescens) spermatozoa (Toth et al., 1997). The concentration of potassium in seminal fluid of paddlefish prevents sperm motility, but cells can be activated after dilution by about four (Linhart et al., 2002) or eight times (Mims, 1991). Linhart et al. (2002) observed a high correlation between osmolality of seminal fluid and concentration of $\mathrm{GnRHa}$, and between velocity of spermatozoa and osmolality of seminal fluid. As a consequence it appears that high osmotic concentration in seminal fluid increases the velocity of paddlefish spermatozoa.

The main aims of the present study were to examine the effects of potassium, calcium and magnesium on the motility of fresh and demembranated spermatozoa of the American paddlefish.

\section{Materials and Methods}

\section{Induction of spermiation and collection of spermatozoa}

The experiments were carried out in March and April at the Aquaculture Research Center, Kentucky State University (Frankfort, KT). Paddlefish of 7.0-12.0 kg were captured below McAlpinne Dam, Louisville, KT.

Five males were selected and held separately in a circular tank (3000 I) with a water flow rate of $12 \mathrm{I} \mathrm{min}^{-1}, 9.0 \mathrm{mg} \mathrm{O}_{2}$ $\mathrm{I}^{-1}$, at controlled water temperature of $17-19^{\circ} \mathrm{C}$. Mature male paddlefish can be identified during the spawning period by the presence of tubercles on their head and opercular flaps.

Spermatogenesis was induced hormonally by i.p. injections of the $\mathrm{GnRH}$ analogue [des-Gly10 (D-Ala6) $\mathrm{GnRH}$ ethylamide] (Sigma, St Louis, MO) at $50 \mu \mathrm{g} \mathrm{kg}^{-1}$ body weight (Linhart et al., 2000). Tygon tubing (5 cm in length) attached to a $10 \mathrm{ml}$ plastic syringe was used to collect spermatozoa. The tubing was inserted into the urogenital pore and the syringe was filled with milt. Spermatozoa were collected and stored in aerobic conditions on wet ice until motility analysis.

\section{Evaluation of sperm motility parameters}

The velocity and percentage of motile spermatozoa were evaluated, and motility parameters were measured under dark field and phase-contrast microscopy (Fig. 1) (Cosson et al., 2000). Spermatozoa were observed for spontaneous movement immediately after collection and before dilution. A drop of $10 \mu \mathrm{l}$ undiluted spermatozoa was spread on a prepositioned glass slide and examined at $\times 200$. The swimming ability of spermatozoa was measured by the addition of $0.5 \mu \mathrm{l}$ spermatozoa to $49 \mu \mathrm{l}$ swimming medium, which was composed of 20 mmol Tris- $\mathrm{HCl} \mathrm{I}^{-1}, \mathrm{pH} 8.2$, with $1 \mathrm{mg}$ bovine serum albumin $\mathrm{ml}^{-1}$ (Sigma A-7511; to prevent cells from adhering to the glass slide) and other component ions, such as $\mathrm{K}^{+}, \mathrm{Mg}^{+}$and $\mathrm{Ca}^{2+}$. The swimming medium was placed on a glass slide previously positioned on the microscope stage, and immediately after mixing with spermatozoa, examined at $\times 200$. In this part of the study, the final dilution was 1:100. Motile spermatozoa were videorecorded beginning $<5 \mathrm{~s}$ after activation for measurement of velocity and percentage of motile spermatozoa. The movements of spermatozoa were observed through a $\times 20$ lens using dark field microscopy and were recorded at 60 frames $\mathrm{s}^{-1}$ using a CCD video camera (Sony SSC-DC50AP) mounted on a dark field microscope (Nikon Optiphot 2). The focal plane was always positioned near the glass slide surface. Sperm movement was recorded using a tape recorder (Sony VHS, SVO 1520), visualized on a colour video monitor (Sony) and using stroboscopic illumination. The stroboscopic flash (Strobex; Chadwick-Helmut, El Monte, CA) illumination with adjustable frequency was set in automatic register with the video frames $(60 \mathrm{~Hz})$. The successive positions of the recorded sperm heads were measured from video frames using a video-recorder (Sony SVHS, SVO-9500 MDP). Velocity and percentage of motile spermatozoa were analysed from five successive frames, each by 'Micro Image Analysis' (Version 4.0 for Windows, special macro of three colours).

For detailed examination of other swimming parameters, such as the flagella beating and wave characteristics, $0.1-0.5 \mu \mathrm{l}$ spermatozoa (by Eppendorf pipette from 0.1 to $2.5 \mu \mathrm{l}$ ) was directly mixed on a glass slide with $49 \mu \mathrm{l}$ distilled water or swimming medium, and a cover slip was added for oil immersion application. Immediately after mixing, sperm motility was recorded under $\times 400$ or $\times 1000$. In this part of the study, the final dilution was between 1:100 and 1:500. Motile spermatozoa were recorded within 6-8 s after activation for measurement of swimming parameters. The movements of the flagellum were recorded with the technique described above, but also using phase-contrast $\times 40$ or $\times 100$ oil immersion lenses. The stroboscopic flash illumination was set manually at an adjustable frequency of $150-800 \mathrm{~Hz}$, depending on the time resolution required. During recording, the microscope stage was slowly moved by hand: this allowed the visualization of multiple well-defined successive images of a motile spermatozoon without overlap of flagella images within every video frame (Cosson et al., 1997).

\section{Demembranation and reactivation of spermatozoa}

Two microlitres of undiluted spermatozoa were mixed with $50 \mu$ l demembranation medium, which was composed 


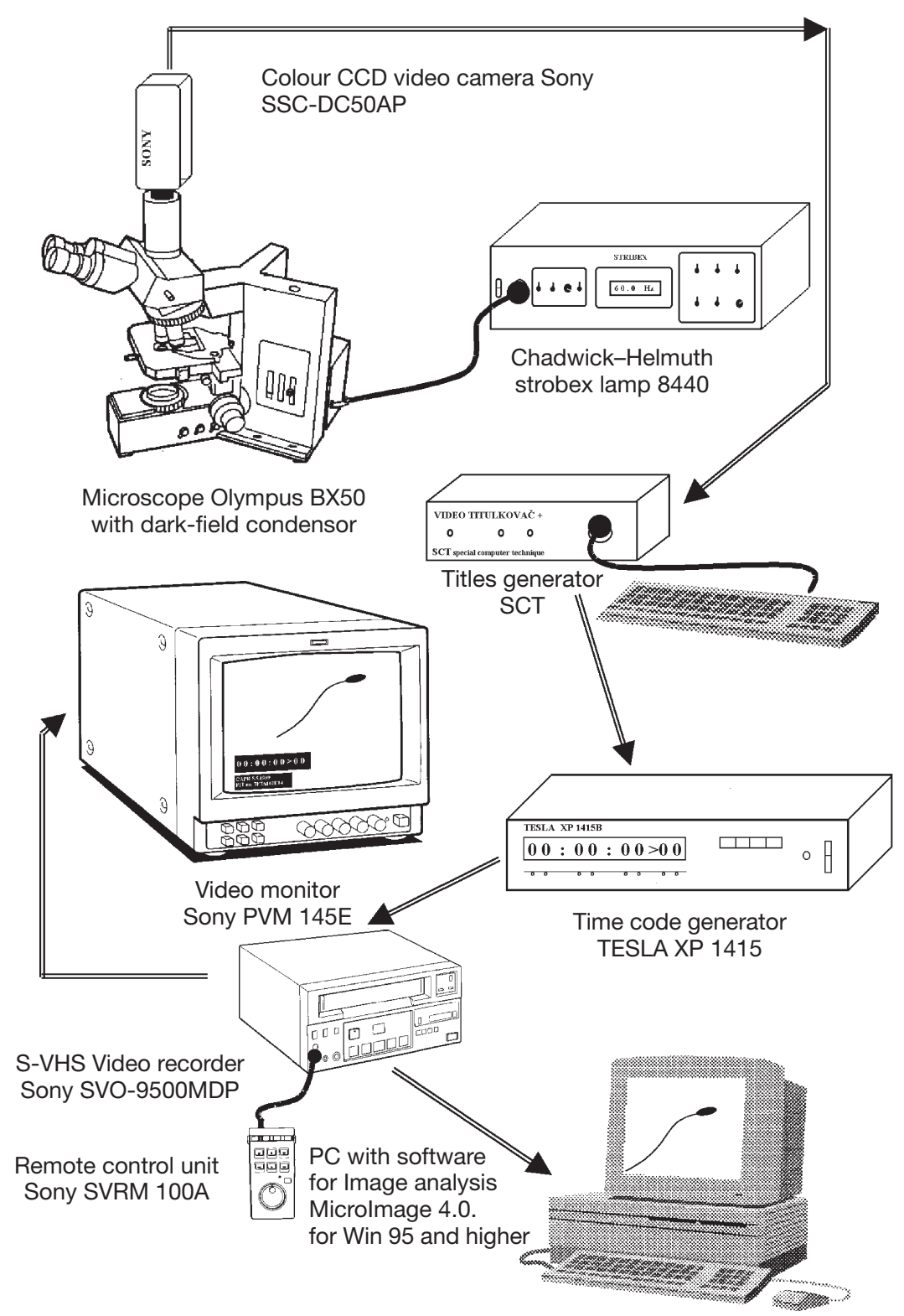

Fig. 1. Equipment for evaluation of sperm motility in paddlefish.

of $20 \mathrm{mmol} \mathrm{NaCl} \mathrm{I}^{-1}, 0.5 \mathrm{mmol}$ EDTA ${ }^{-1}$ (Sigma), $1 \mathrm{mmol}$ dithiothreitol $\mathrm{I}^{-1}$ (DTT, Sigma D-0632), $20 \mathrm{mmol}$ Tris- $\mathrm{HCl}$ $\mathrm{I}^{-1}, \mathrm{pH} 8.2$ and $0.04 \%$ Triton-X100 at $0^{\circ} \mathrm{C}$. After $30 \mathrm{~s}$ at $0^{\circ} \mathrm{C}$, a $2 \mu \mathrm{l}$ aliquot was pipetted and mixed at room temperature $\left(18-20^{\circ} \mathrm{C}\right)$ on the glass slide with $50 \mu \mathrm{l}$ of reactivation medium $\left(20 \mathrm{mmol} \mathrm{NaCl} \mathrm{I}^{-1}, 1 \mathrm{mmol}\right.$ DTT I-1, $20 \mathrm{mmol}$ Tris- $\mathrm{HCl} \mathrm{I}^{-1}$, pH 8.2, $1 \mathrm{mmol} \mathrm{MgCl}_{2} \mathrm{I}^{-1}, 2 \mathrm{mg} \mathrm{BSA} \mathrm{ml}^{-1}$ and 1 mmol ATP $\mathrm{I}^{-1}$, vanadate free from Boehringer). BSA was required to prevent the sperm cells from adhering to glass or

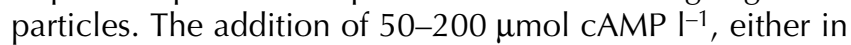
demembranation or reactivation media, was necessary to initiate motility. The swimming ability of spermatozoa was assessed as described above.

\section{Statistical analysis}

The data acquired from several replications were evaluated and statistical significance was assessed using ANOVA (Statgraphics version 5), followed by multiple comparison tests. Probability values of $P<0.05$ were considered significant.

\section{Results}

Motility of undiluted and diluted spermatozoa in swimming medium

Direct observation of undiluted spermatozoa by dark field microscopy showed that most spermatozoa in the 


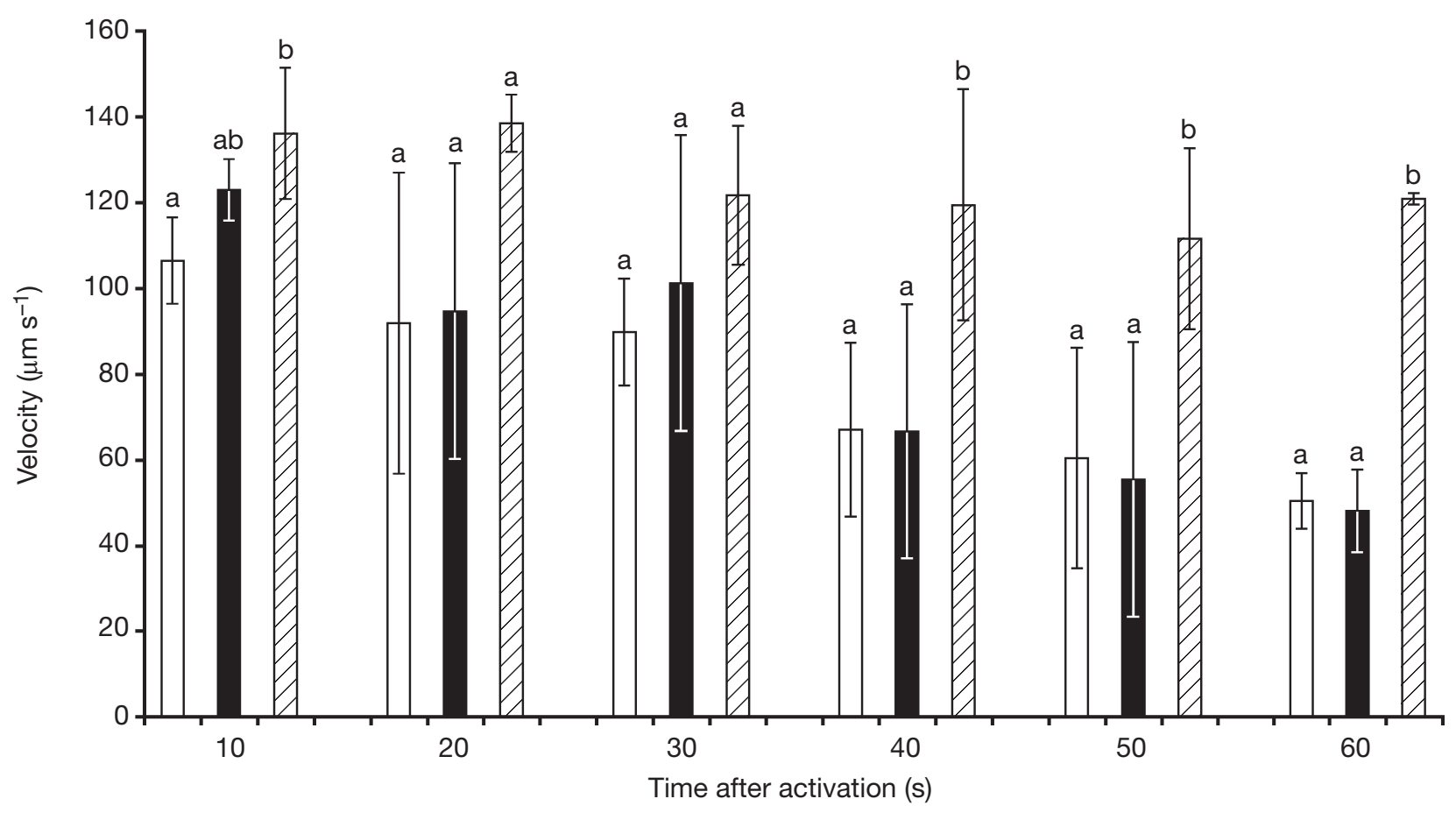

Fig. 2. Velocity of paddlefish (Polyodon spathula) spermatozoa activated with $5 \mathrm{mmol} \mathrm{CaCl}_{2} \mathrm{I}^{-1}(\square)$ and swimming medium (20 mmol Tris- $\mathrm{HCl} \mathrm{I}^{-1}$ at pH 8.2 and BSA), with $5 \mathrm{mmol} \mathrm{MgCl}_{2} \mathrm{I}^{-1}(\mathbf{\square})$ and swimming medium, or with swimming medium only (control, $\square)$. Values are mean \pm SD. abColumns within the same swimming periods (10, 20, 30, 40, 50 and $60 \mathrm{~s}$ after activation) with a common superscript are not significantly different $(P<0.05)$.

seminal plasma of paddlefish were immotile, but that the flagella were straight and shivered slightly. Only a few spermatozoa were motile for $<10 \mathrm{~s}$.

When transferred into swimming medium, paddlefish spermatozoa were immediately activated and displayed the following characteristics: (i) $100 \%$ of spermatozoa were motile at $10 \mathrm{~s}$ after activation with a velocity of 130-160 $\mu \mathrm{m}$ $\mathrm{s}^{-1}$; (ii) after $2 \mathrm{~min}$, the velocity decreased to $80-130 \mu \mathrm{m} \mathrm{s}^{-1}$; and (iii) motility was maintained for up to $9 \mathrm{~min}$.

\section{Inhibitory effect of low ionic concentrations}

The motility of paddlefish spermatozoa in low concentrations of $\mathrm{KCl}, \mathrm{MgCl}_{2}, \mathrm{NaCl}$ or $\mathrm{CaCl}_{2}$ solution in swimming medium (20 mmol Tris- $\mathrm{HCl} \mathrm{I}^{-1}$ at $\mathrm{pH} 8.2$ and BSA) was investigated. The spermatozoa were highly motile in swimming medium with low concentrations $\left(0.5-5.0 \mathrm{mmol} \mathrm{I}^{-1}\right)$ of $\mathrm{NaCl}, \mathrm{MgCl}_{2}$ or $\mathrm{CaCl}_{2}$. Concentrations of $0.5-5.0 \mathrm{mmol}$ $\mathrm{KCl} \mathrm{I}^{-1}$ did not initiate sperm motility. When swimming medium containing $0.5 \mathrm{mmol} \mathrm{KCl} \mathrm{\textrm {I } ^ { - 1 }}$ was combined with $5.0 \mathrm{mmol} \mathrm{NaCl}{ }^{-1}$ or $\mathrm{MgCl}_{2}, 80-100 \%$ of spermatozoa became motile with a velocity of about $120-150 \mu \mathrm{m} \mathrm{s}^{-1}$. $\mathrm{MgCl}_{2}$ significantly improved velocity of sperm motility at 10, 40, 50 and $60 \mathrm{~s}$ after activation (Fig. 2) and stable velocity of spermatozoa was $140 \mu \mathrm{m} \mathrm{s}^{-1}$ at 2 min after activation. A low concentration of $\mathrm{KCl}\left(1 \mathrm{mmol} \mathrm{I}^{-1}\right)$ fully inhibited sperm movement, but motility was re-initiated by the addition of a low concentration of $\mathrm{CaCl}_{2}$. A solution of
$0.125 \mathrm{mmol} \mathrm{CaCl}_{2} \mathrm{I}^{-1}$ and $0.5 \mathrm{mmol} \mathrm{KCl} \mathrm{^{-1 }}$ resulted in movement of $20 \%$ of the spermatozoa, whereas $100 \%$ of the spermatozoa were activated by the addition of

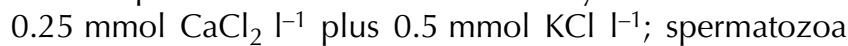
swim for $2 \mathrm{~min}$ at a velocity of about $120 \mu \mathrm{m} \mathrm{s}^{-1}$. In addition, spermatozoa were activated in higher concentrations of $\mathrm{KCl}\left(5 \mathrm{mmol} \mathrm{I}^{-1}\right)$ and $3 \mathrm{mmol} \mathrm{CaCl}_{2} \mathrm{I}^{-1}$ final concentration, resulting in $50-60 \%$ motile sperm cells. All spermatozoa were fully motile after combining $5 \mathrm{mmol} \mathrm{KCl}^{-1}$ plus $5 \mathrm{mmol}$ of $\mathrm{CaCl}_{2} \mathrm{I}^{-1}$; velocity was about $120 \mu \mathrm{m} \mathrm{s}^{-1}$ at $2 \mathrm{~min}$ after activation. Paddlefish spermatozoa inhibited with $0.5 \mathrm{mmol} \mathrm{KCl} \mathrm{I-1}^{-1}$ could be activated in a solution composed

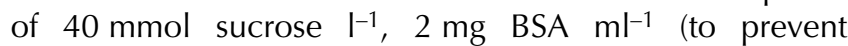
spermatozoa adhering to the glass slide) and at $125 \mu \mathrm{mol}$ $\mathrm{CaCl}_{2}{ }^{-1}$. Low concentrations of $\mathrm{Ca}^{2+}$ appeared to reverse the inhibitory effects of $0.5 \mathrm{mmol} \mathrm{KCl}{ }^{-1}$. In addition, the EGTA used to complex $\mathrm{Ca}^{2+}$ could abolish the protective calcium ion effect. In the latter case $\mathrm{Ca}^{2+}$ combined with the calcium ionophore A23187 completely re-established the inhibitory effect of $\mathrm{K}^{+}$probably by increasing of $\mathrm{Ca}^{2+}$ permeability of the sperm membrane.

\section{Demembranation and reactivation of spermatozoa}

In this experiment, the inhibitory effect of $\mathrm{K}^{+}$on the axonemes of demembranated spermatozoa (Fig. 3 ) in the reactivating solution containing ATP was examined. The presence of $\mathrm{KCl}$ or $\mathrm{K}^{+}$at $5-15 \mathrm{mmol} \mathrm{I}^{-1}$ was used to inhibit 

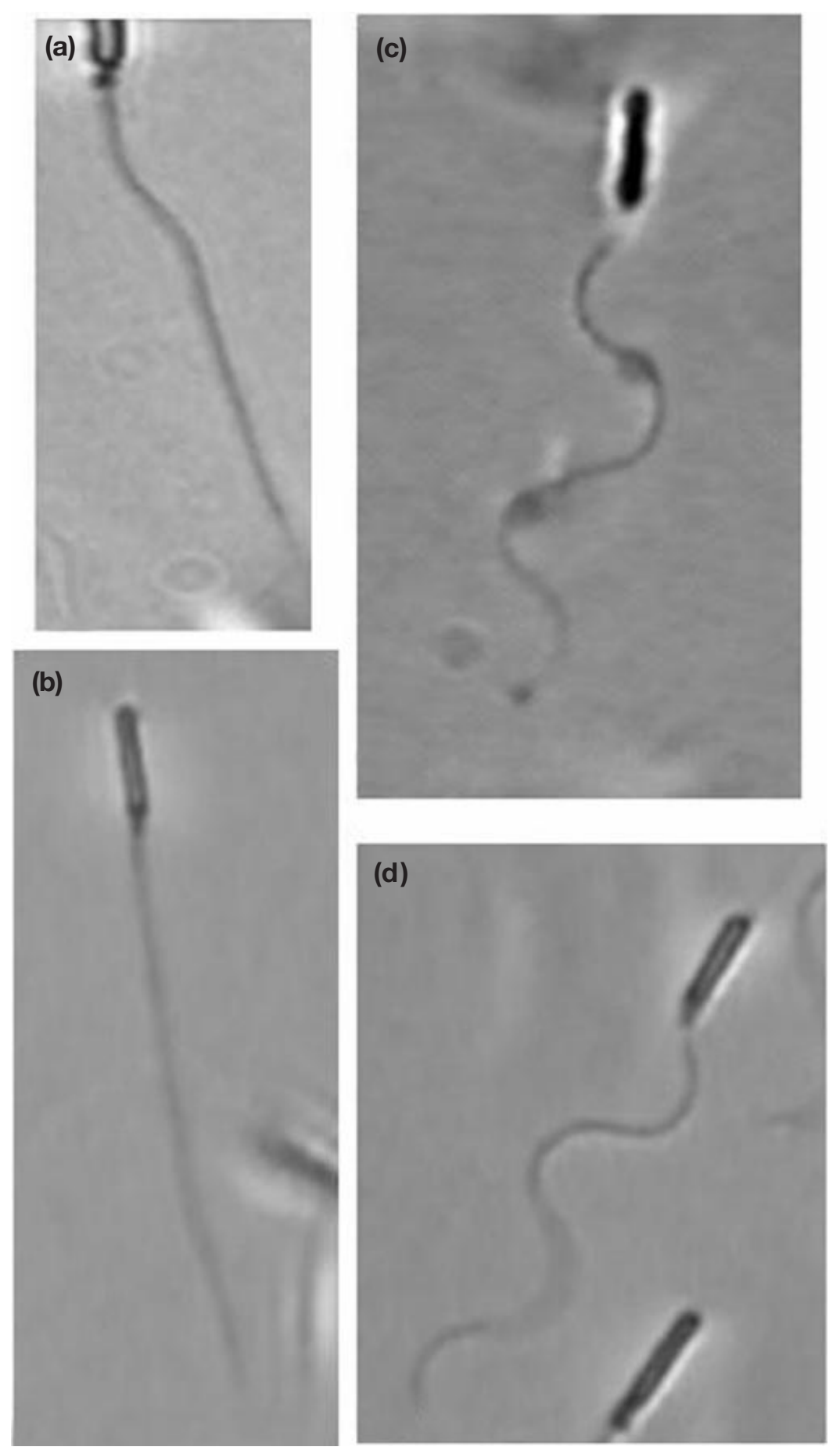

Fig. 3. (a) Shivering, not activated spermatozoa with membrane, (b) resting demembranated spermatozoa, (c) fully-activated spermatozoa with membrane damaged by low osmotic shock (distilled water) and (d) fully activated demembranated spermatozoa of the paddlefish (Polyodon spathula).

demembranated flagella. The addition of $20 \mathrm{mmol} \mathrm{NaCl}^{-1}$ allowed reactivation of fully demembranated sperm flagella

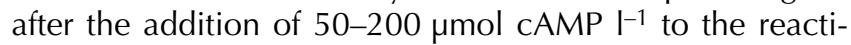
vated medium. The effect on motility was greater when the spermatozoa were demembranated and reactivated in solution demembranated medium and reactivated medium, respectively, both containing $0.5 \mathrm{mmol} \mathrm{CaCl} \mathrm{l}^{-1}$. The functional sensitivity of sturgeon axonemes to $\mathrm{Ca}^{+}$was confirmed. Even when using demembranated medium and reactivated medium without $\mathrm{K}^{+}$but with $\leqslant 100 \mu \mathrm{mol} \mathrm{CaCl}{ }_{2}$ 
$\mathrm{I}^{-1}$ in reactivated medium, the flagella of demembranated ATP-reactivated spermatozoa had only twitching motion with a very small wave amplitude. In contrast, waves with large amplitude developed when the reactivated medium contained $\geqslant 250 \mu \mathrm{mol} \mathrm{CaCl}{ }_{2}{ }^{-1}$.

\section{Discussion}

Spermatozoa of sturgeons and paddlefish are essentially immotile in the seminal plasma (Cosson and Linhart, 1996), but are fully activated when transferred into swimming medium. Fish spermatozoa are generally immotile in the testes and seminal plasma. Environmental factors, such as ions, $\mathrm{pH}$ or osmolality, may lead to the depolarization of the cell membrane and, therefore, stimulate motility of spermatozoa (Cosson et al., 1999). Several generations of paddlefish spermatozoa are present in the testis at the same time. The motility of paddlefish spermatozoa is inhibited by an increase in $\mathrm{K}^{+}$concentration even at $\mathrm{pH}$ values of 7.0 (Cosson and Linhart, 1996). No cumulative effect of $\mathrm{Ca}^{2+}$ was observed in paddlefish as described for salmonids by Scheuring (1925), Billard (1978), Cosson et al. (1986, 1989) and Christen et al. (1987). In the case of paddlefish spermatozoa, motility is sensitive to very low concentrations of $\mathrm{K}^{+}\left(0.5 \mathrm{mmol} \mathrm{I}^{-1}\right)$, which is lower than that for salmonids (Cosson et al., 1986; Morisawa et al., 1983). The potential for movement in paddlefish spermatozoa was preserved after dilution in a $5 \mathrm{mmol} \mathrm{KCl} \mathrm{I}^{-1}$ plus $20 \mathrm{mmol}$ Tris- $\mathrm{HCl} \mathrm{I}^{-1}$ at $\mathrm{pH}$ 8. This solution also regenerated the sperm potential for movement, especially when the $\mathrm{pH}$ of fresh spermatozoa was $<7$, which might be due to urine contamination (Cosson and Linhart, 1996). A similar regenerative effect of $\mathrm{K}^{+}$was reported by Redondo et al. (1991) for carp spermatozoa, but using a medium of high osmotic pressure $(380 \mathrm{mOsmol})$, in contrast to paddlefish spermatozoa, for which the effect of regeneration was observed at a lower osmotic pressure $(40 \mathrm{mOsmol})$. The spermatozoa of paddlefish were motile in a range of osmotic pressures

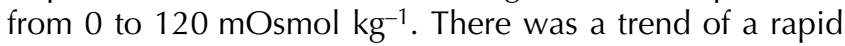
reduction from 80 to $0 \%$ sperm motility with increases in osmotic pressure from 70 to $120 \mathrm{mOsmol} \mathrm{kg}{ }^{-1}$ (Linhart et al., 1995). The effects of the $\mathrm{KCl}, \mathrm{CaCl}_{2}$, glucose and $\mathrm{Li}_{2} \mathrm{CO}_{3}$ were also tested by Cosson and Linhart (1996). Sperm movement was inhibited in solutions of $120 \mathrm{mmol}$ glucose $\mathrm{I}^{-1}$ or $10 \mathrm{mmol} \mathrm{CaCl}_{2} \mathrm{I}^{-1}$ in combination with $20 \mathrm{mmol}$ Tris- $\mathrm{HCl} \mathrm{^{-1 }}$ at $\mathrm{pH}$ 8. The spermatozoa were motile in

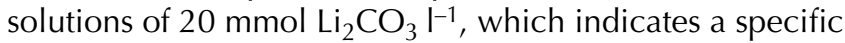
effect for $\mathrm{K}^{+}$. No cumulative effect on storage time of spermatozoa was observed between $1 \mathrm{mmol} \mathrm{KCl} \mathrm{I}^{-1}$ and

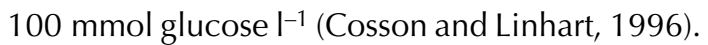

A demembranated flagellum is directly in contact with chemicals and the potential of the motility 'effectors' can be tested directly. Demembranation is obtained by application of a mild non-ionic detergent (for example Triton-X100) and reactivation is initiated by addition of $\mathrm{ATP}-\mathrm{Mg}^{2+}$, the substrate of flagella dynein-ATPases (Gibbons and Gibbons, 1972). In this respect, the present study demonstrated that inhibition of fresh or demembranated spermatozoa was effected with low concentration of $\mathrm{K}^{+}\left(0.5 \mathrm{mmol} \mathrm{I}^{-1}\right)$ and that this effect was eliminated usually with low $\mathrm{Ca}^{2+}$ concentration or replacement of $\mathrm{K}^{+}$by $\mathrm{Na}^{+}$in demembranated flagella.

The results from the present study indicate that movement of paddlefish spermatozoa is not significantly influenced by osmotic pressure (Linhart et al., 1995; Cosson and Linhart, 1996), but is under reciprocal control of the concentration of $\mathrm{K}^{+}$and $\mathrm{Ca}^{2+}$. In this respect, paddlefish spermatozoa are more similar to those of salmonids than cyprinids (Billard, 1978; Billard et al., 1995 and Morisawa et al., 1983).

This work was supported by USDA 1890 Capacity Building Grant Program (KYX-01-11469) Kentucky State University, Frankfort, KY. This project was funded by the CNRS-France (J. Cosson), Czech Grand Foundation and Ministry of Education no. J06/98:126100001, Czech Republic (O. Linhart and M. Rodina) and Embassy of France in Prague.

\section{References}

Adams LA (1942) Age determination and rate of growth in Polyodon spathula by means of the growth rings of the otoliths and dentary bones American Wildlife Nature 28 617-630

Ballard WW and Needham RG (1964) Normal embryonic stages of Polyodon spathula (Walbaum) Journal of Morphology 114 465-478

Billard R (1978) Changes in structure and fertilizing ability of marine and fresh water fish spermatozoa diluted in media of various salinities Aquaculture 14 187-198

Billard R, Cosson J, Perchec G and Linhart O (1995) Biology of sperm and artificial reproduction in carp Aquaculture 129 95-112

Carlson DM and Bonislawsky PS (1981) The paddlefish (Polyodon spathula) fisheries of the midwestern Fisheries 6 (2) 17-22, 26-27

Christen R, Gatti JL and Billard R (1987) Trout sperm motility European Journal of Biochemistry 166 667-671

Cosson J and Linhart O (1996) Paddlefish (Polyodon spathula) spermatozoa: effects of potassium and $\mathrm{pH}$ on motility Folia Zoologica 45 361-370

Cosson MP, Billard R, Carre D, Letellier L, Christen R, Cosson J and Gatti JL (1986) Control of flagellar movement in ' $9+2$ ' spermatozoa: calcium and cyclic AMP dependent chemotactic behavior Cell Motility and the Cytoskeleton 6237

Cosson MP, Billard R and Letellier L (1989) Rise of internal $\mathrm{Ca}^{2+}$ accompanies the initiation of trout sperm motility Cell Motility and the Cytoskeleton 14 424-434

Cosson J, Billard R, Cibert C, Dreanno C, Linhart O and Suquet M (1997) Movements of fish sperm flagella studied by high speed videomicroscopy coupled to computer assisted image analysis Poliskie Archiwum Hydrobiologii 44 103-113

Cosson J, Billard R, Cibert C, Dréanno C and Suquet M (1999) lonic factors regulating the motility of fish sperm. In From Basic Science the Male Gamete to Clinical Application pp 161-186 Eds C Gagnon. Cache River Press, Vienna, IL

Cosson J, Linhart O, Mims SD, Shelton WL and Rodina M (2000) Analysis of motility parameters from paddlefish (Polyodon spathula) and shovelnose sturgeon (Scaphirhynchus platorynchus) spermatozoa Journal of Fish Biology 56 1348-1367

Drabkina BM (1961) Effect of different water salinities on the survival rate of spermatozoa, eggs and larvae of sturgeon Doklady AN SSSR 138 492-495 (in Russian)

Folz DJ and Mezers LS (1985) Management of the lake sturgeon, Acipenser fulvescens, population in the Lake Winnebago system, Wisconsin. In Natural American Sturgeons Biology Aquaculture and Potential pp 135-146 Eds FP Binkowski and SI Doroshov. Junk Publishers, Dordrecht 
Gengerke TW (1986) Distribution and abundance of paddlefish in the United States. In The Paddlefish: Status, Management and Propagation pp 22-35 Eds JG Dillar, LK Graham and TR Russell. North Central Division, American Fisheries Society Special Publication 7, Bethesda, MD

Gibbons BH and Gibbons IR (1972) Flagellar movement and adenosine triphosphatase activity in sea urchin sperm extracted with Triton-X100 Journal of Cell Biology 54 75-97

Graham LK, EJ Hamilton, TR Russell and CE Hicks (1986) The culture of paddlefish - a review of methods. In The Paddlefish: Status, Management and Propagation pp 78-94 Eds JG Dillard, LK Graham and TR Russell. North Central Division, American Fisheries Society Special Publication 7, Bethesda, MD

Kroll KJ, Vaneenennaam JP, Doroshov SI and Linares J (1994) Growth and survival of paddlefish fry raised in the laboratory on natural and artificial diets Progressive Fish-Culturist 56 169-174

Linhart O, Mims SD and Shelton WL (1995) Motility of spermatozoa from shovelnose sturgeon (Scaphirhynchus platorynchus, Rafinesque, 1820) and paddlefish (Polyodon spathula, Walbaum, 1792) Journal of Fish Biology 47 902-909

Linhart O, Mims SD, Gomelsky B, Hiott AE, Shelton WL, Cosson J, Rodina M and Gela D (2000) Spermiation of paddlefish (Polyodon spathula, Acipenseriformes) stimulated with injection of LHRH analogue and carp pituitary powder Aquatic Living Resources 13 455-460

Linhart O, Mims SD, Gomelsky B, Hiott AE, Shelton WL, Cosson J, Rodina M, Gela D and Bastl J lonic and osmolality level of paddlefish (Polyodon spathula Acipenseriformes) seminal fluid with sperm motility parameters Aquaculture International (in press)

Liu C and Zeng Y (1988) Notes on the Chinese paddlefish Psephurus gladius (Martens) Copeia 484-487

Mims SD (1991) Evaluation of activator solutions, motility duration and short-term storage of paddlefish spermatozoa Journal of World Aquaculture Society $22224-229$

Mims SD and WL Shelton (1998) Monosex culture of paddlefish and shovelnose sturgeon. In Symposium on Harvest, Trade and Conservation of North American Paddlefish and Sturgeon pp 67-76 Eds DF Williamson, GW Benz and CM Hoover. TRAFFIC North America/World Wildlife Fund, Washington DC

Mims SD, Georgi TA and Chen-Han L (1993a) The Chinese paddlefish, Psephurus gladius: biology, life history and potential for cultivation Journal of World Aquaculture Society 24 45-48

Mims SD, Clark JA, Williams JC and Rouse DB (1993b) Comparisons of two by-products and a prepared diet as organic fertilizers on growth and survival of larval paddlefish Polyodon spathula in earthen ponds Journal of Applied Aquaculture 2 171-187

Morisawa M and Suzuki K (1980) Osmolality and potassium ion: their roles in initiation of sperm motility in teleosts Science 210 1145-1147

Morisawa M, Suzuki K and Morisawa S (1983) Effects of potassium and osmolality on spermatozoa motility of salmonid fishes Journal of Experimental Biology 107 105-113

Needham RG (1965) Spawning of paddlefish induced by means of pituitary material Progressive Fish-Culturist 27 13-19

Purkett CA, Jr (1963) Artificial propagation of paddlefish Progressive FishCulturist 25 31-33

Redondo-Müller C, Cosson MP, Cosson J and Billard R (1991) In vitro maturation of the potential for movement of carp spermatozoa Molecular Reproduction and Development 29 259-270

Scheuring L (1925) Biologishe und physiologische Untersuchungen an Forellensperma Archiw Hydrobiology Supplement 4 181-318

Toth GP, Ciereszko A, Christ SA and Dobrowski K (1997) Objective analysis of sperm motility in the lake sturgeon (Acipenser fulvescens): activation and inhibition conditions Aquaculture 154 337-348

Received 4 March 2002

First decision 18 April 2002.

Revised manuscript received 23 July 2002.

Accepted 1 August 2002. 